\title{
The clinician's perspective on the 21-gene assay in early breast cancer
}

\author{
Francesco Cognetti ${ }^{1}$ and Giuseppe Naso ${ }^{1}$ \\ ${ }^{1}$ Department of Clinical and Molecular Medicine, University La Sapienza, Rome, Italy \\ Correspondence to: Francesco Cognetti, email: francesco.cognetti@ifo.gov.it \\ Keywords: Oncotype DX test; recurrence score results; multigene assays; genomic tests; personalized medicine \\ Received: September 11,2021 Accepted: November 10,2021 Published: December 21, 2021
}

Copyright: $\odot 2021$ Cognetti and Naso. This is an open access article distributed under the terms of the Creative Commons Attribution License (CC BY 3.0), which permits unrestricted use, distribution, and reproduction in any medium, provided the original author and source are credited.

\section{ABSTRACT}

Most patients with early HR+ and HER2- breast cancer receive a hormone therapy; the clinical question still open is how to identify patients who can really benefit from adjuvant chemotherapy. The accurate identification of these patients is essential to avoid an over-treatment, increasing the risk of an unnecessary toxicity; on the contrary, the omission of chemotherapy can deprive high risk patients of a potential life-saving treatment (under-treatment). Several multigene assays (MGAs), assessing the risk of relapse according to the biological characteristics of the tumor, have been developed. To date, the 21-gene assay (Oncotype DX Breast Recurrence Score ${ }^{\circledR}$ ) is the only test developed and validated to be actionable, i.e., able to predict the benefit of adjuvant chemotherapy. The different available tests can be classified according to their clinical utility based on their prognostic and predictive value. A prognostic test gives information about the outcome of the disease, regardless of the administered therapy. When the aim of the test is to drive the treatment decisions, the predictive component, and therefore the ability to accurately identify which patients could benefit from chemotherapy, is essential. This review summarizes the clinical evidences of the Oncotype $D X^{\circledR}$ test supporting its clinical utility.

\section{INTRODUCTION}

Most patients with early HR+ and HER2- breast cancer receive a hormone therapy; the clinical question still open is how to identify patients who can really benefit from adjuvant chemotherapy. The accurate identification of these patients is essential to avoid an over-treatment, increasing the risk of an unnecessary toxicity; on the contrary, the omission of chemotherapy can deprive high risk patients of a potential life-saving treatment (under-treatment). This review analyzes the main characteristics of the genomic tests developed to help oncologists to improve the patient's prognosis, with a special focus on Oncotype DX ${ }^{\circledR}$.

\section{THE TREATMENT OF THE EARLY BREAST CANCER (EBC)}

Classification and epidemiology

The breast cancer represents $24 \%$ of all tumors and it is globally responsible for $15 \%$ of cancer death.
Breast cancer is the most frequent cancer in women and the first cause of death for cancer in women. In Italy [1] 53.000 new cases of breast cancer have been estimated in 2019. The breast cancer is the most diagnosed cancer in women ( $30 \%$ of malignant tumours), with a different rate depending on age: $40 \%$ in patients aged $0-50$ years; $35 \%$ in patients aged $50-69$ years and $22 \%$ in patients aged $>70$ years.

The personalized medicine in early breast cancer

Estrogen Receptors (ERs) and/or Progesterone Receptors (PgRs) are present on the surface of the neoplastic cells in about $75 \%$ of all breast cancers. These tumors, called luminal tumors due to the fact that they seem to originate mainly from the luminal cells of the galactophor ducts and lobules, are all theoretically hormone-responsive at any stage of disease and they are mainly treated with hormone therapy (SERM, LHRH Analogues, Aromatase Inhibitors (AIs), SERD). In case of metastatic disease, a m-TOR inhibitor (Everolimus), an inhibitor of the catalytic domain of Phosphatidyl 
Inositol 3-Chinase (PI3KCa) or a CDK4/6 (cyclindependent kinase 4 and 6) inhibitor may be added to the hormone therapy, if the patient's condition allows it. In patients undergoing surgery for early stage hormoneresponsive breast cancers (local or locally advanced for involvement of ipsilateral axillary lymph nodes), the standard therapeutic approach for the prevention of local disease recurrence and metastases mainly consist of hormone therapy (HT: LHRH-analogues, SERM, AIs). The main challenge of oncologists is to decide when to consider hormone therapy alone or when to add chemotherapy $(\mathrm{CT})$.

\section{Risk evaluation}

The risk of distant relapses is continuous, especially for ER + breast cancers, which account for almost half of metastatic cases [2]. To date, it is not clear whether adjuvant $\mathrm{CT}$ can effectively prevent these recurrences. An overview performed by the Early Breast Cancer Trialists' Collaborative Group (EBCTCG) in 2012, showed a limited benefit from CT (about 10\% of patients) and, mostly, the inability to identify a subgroup of patients who could significantly benefit from CT, based on clinical and pathological characteristics only [3]. The choice of the adjuvant $\mathrm{CT}$ is therefore particularly complex and based on histological, pathological and immunohistochemical characteristics of the tumour, as well as on the patient's condition.

The main prognostic parameters used to evaluate the risk of metastasis, and consequently the most suitable therapy, are: age ( $<35$ years: worst prognosis), tumour size, histological grade and type $(\mathrm{G})$, presence of axillary lymph nodes metastases, lympho-vascular invasion, hormonal receptor status (HR), human epidermal growth factor 2 (HER2) receptor status, proliferative activity (evaluated through the molecular marker Ki-67) and gene expression profiles [4].

All these parameters allow oncologists to establish the prognosis of the patient with a good approximation; consequently, the therapeutic choice is based on the extrapolation that $\mathrm{CT}$ combined with hormone therapy is required in patients with a worse prognosis. High proliferative ER+/HER2 - tumours are considered chemosensitive; on the contrary, low proliferative ER+/HER2tumours hormone-sensitive [5].

However, traditional parameters are not able to establish the proliferative activity of the tumour in a reproducible and reliable manner [4]. For example, the evaluation of the proliferative activity with the Ki-67 labeling index, a nuclear antigen expressed during cell proliferation phases (G1, S, G2, M) but not by quiescent cells, is not reproducible due to the lack of standardized procedures for reading and interpreting results [6]. Relying only on clinical parameters, oncologists have some tools able to predict the prognosis of the disease and the benefit coming from hormone therapy (presence of ER), but they have no predictive data of the possible benefit from adding CT. Moreover, the interpretation of the clinical parameters is different among oncologists, so there is a lack of homogeneity of the adjuvant therapy for women with breast cancer after surgery. Finally, the use of unnecessary $\mathrm{CT}$ is associated with considerable burden for the patient who do not derive any clinical benefit.

\section{Critical aspects of the adjuvant therapy}

Chemotherapy can cause a temporary or permanent moderate-severe disability, which has a negative impact on the quality of life and professional career of patients and family members [7]. Patients treated with CT tend to be absent from work longer (9.5 months with CT vs. 5.4 months without CT) and are often forced to leave their professional career ( $21 \%$ with CT vs. $14 \%$ without CT). Similarly, $52 \%$ of family members of patients receiving $\mathrm{CT}$ are absent from work for providing care [8].

The importance of carefully assessing the toxicity of the CT compared to its potential benefits is strictly linked to the possible long-term side effects, arising during the treatment period and generally resolving within a few months, and "late-chronic" side effects, occurring many years after the end of adjuvant $\mathrm{CT}$ and often lasting for several years $[9,10]$.

Only $10 \%$ of patients with early ER+ breast cancer, which account for about $75 \%$ of breast cancers [4], clearly benefit from CT (Figure 1) [3]. It is therefore important to have decision-making tools driving the treatment choice, in order to avoid the CT-associated toxicity. The analysis of the tumour gene profile is essential in patients with ER+ cancers for better defining the prognosis and, when possible, being predictive of treatment response for driving the therapeutic choice related to the use of CT [5].

Genomic tests, developed and marketed in recent years could be a possible way to meet these objectives [4].

\section{MULTIGENE ASSAYS SUPPORTING THE CLINICAL DECISIONS}

\section{The MGAs approved in Italy}

Due to the clinical and molecular heterogeneity of breast cancer, several genomic tests have been developed to help oncologists to improve the patient's prognosis (Oncotype DX, EndoPredict, Prosigna, MammaPrint) and to predict chemotherapy benefit in order to choose the most appropriate adjuvant therapy (Oncotype DX) [4].

In Italy, all 4 genomic tests are available for early breast cancers. The tests are not equivalent: in fact, they have been designed to evaluate the different gene profile and to address different questions (Table 1). 


\section{Differences and characteristics of the MGAs approved in Italy: prognostic and predictive value}

Table 1 shows the main characteristics of the 4 MGAs. Due to the different gene panels, genomic tests cannot be considered similar. The tests also differ in their purposes (prognostic and/or predictive value) and consequently in the different validation studies.

The possibility to provide an estimate of the relapse risk (prognostic value) compared to the benefit from CT (predictive value) is undoubtedly one of the most important and distinctive aspects. A prognostic test provides information on the natural history of the disease and on the risk an event appears (e.g., distant relapse). Therefore, prognostic tests can suggest the need for adjuvant therapy, but do not give information about the probability of response to a specific treatment. A genomic prognostic test is generally validated by a retrospective analysis of biopsy samples collected in randomised controlled clinical trials or observational trials performed on untreated patients (as in case of MammaPrint) or patients treated with hormone therapy alone (Endopredict, Prosigna, and the Oncotype DX test) [11]. The relationship between the test and the clinical outcome of the patient treated with hormone therapy will establish the prognostic value of the biomarker and complement traditional clinical pathological factors to refine prognosis.

A biomarker is considered "predictive" if it is associated to a clinical outcome in a strictly treatmentdependent manner and it is generally validated in prospective studies. Thus, a genomic test for early breast cancer is truly predictive when a statistically significant correlation among biomarker, the treatment group (es. CT vs. no CT) and the patient's outcome is demonstrated [12].

Today, the Oncotype DX test is the only test considered predictive, supported by evidence from clinical studies designed to assess its clinical utility in guiding clinicians in their therapeutic choice. Clinical evidence shows that, overall, patients with a high value of the Recurrence Score results (RS 26-100) benefit from CT, while high values of other genomic tests, such as Prosigna or EndoPredict, reflect a high risk for recurrence without information on benefit from treatment [13]. Similarly, the MINDACT trial did not provide definitive information on the benefit of adjuvant CT for patients with high MammaPrint results [14].

In our clinical practice our main question is to identify the few patients who could effectively benefit from chemotherapy; hence we focus this review on the predictive test for chemotherapy, the Oncotype DX test.

\section{THE ONCOTYPE DX TEST}

The Oncotype DX test is a molecular test based on the qRT-PCR technology aimed to evaluate the expression of 21 genes (Figure 2) on a surgical or core biopsy sample of neoplastic breast tissue. The analysis is indicated in patients with early HR+, HER2- N0 or N1 (1-3 lymph nodes) breast cancer and can provide the likelihood of long-term tumour relapse (prognostic component), as well as the possible response to adjuvant CT (predictive component).

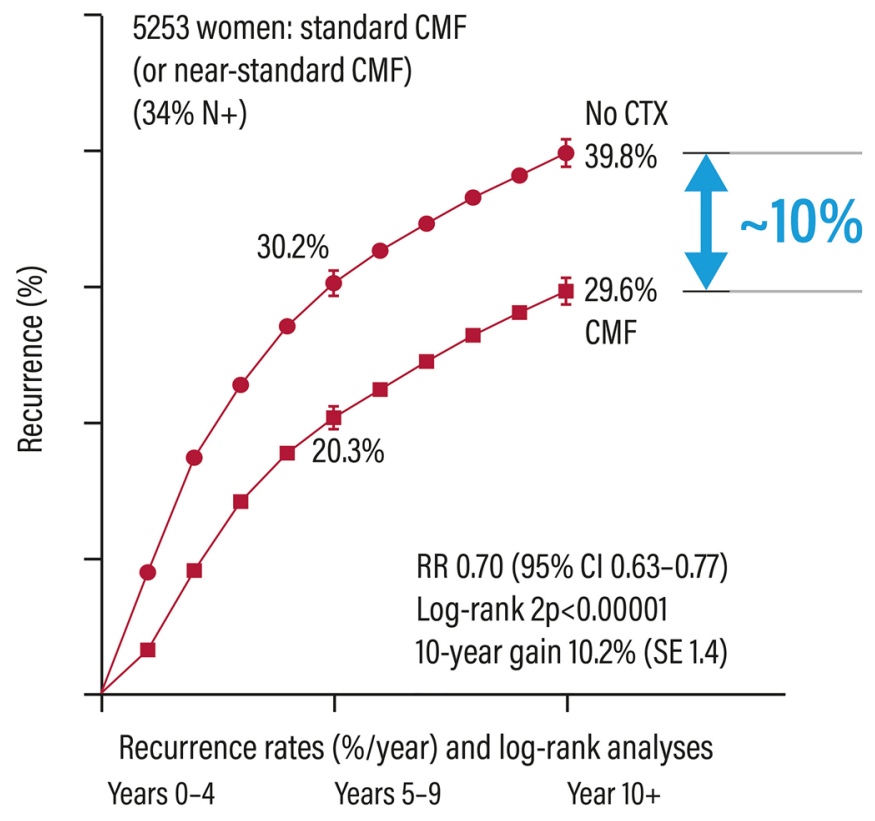

Figure 1: Relapse rates in patients with early breast cancer treated or not with adjuvant chemotherapy. Abbreviations: $\mathrm{Cl}$ : confidence interval; CMF: cyclophosphamide/methotrexate/5-fluorouracil; CTX: chemotherapy; RR: risk ratio. 
Table 1: Breast cancer genomic signature platforms

\begin{tabular}{|c|c|c|}
\hline $\begin{array}{l}\text { Oncotype DX }{ }^{\circledR} \\
\text { EndoPredict }^{\circledR}\end{array}$ & MammaPrint $^{\circledR}$ & Prosigna $^{\mathrm{TM}}$ \\
\hline RT-PCR gene expression & RNA gene microarray & Hybridization with gene specific labels \\
\hline Quantitative (continuous) & Qualitative (binary) & Quantitative (continuous) \\
\hline $\begin{array}{l}\text { Gene expression levels of relatively } \\
\text { small number of genes }\end{array}$ & $\begin{array}{l}\text { Gene expression levels of large } \\
\text { number of genes }\end{array}$ & $\begin{array}{l}\text { Gene expression levels of relatively large } \\
\text { number of genes }\end{array}$ \\
\hline High precision & Modest precision & Moderate to high precision \\
\hline
\end{tabular}

\section{Standard and quality control}

The tumour samples are sent to a centralized laboratory in a specially prepared container, enclosed in a transport kit. The test is performed in the United States on a single platform according to the required quality standards (Clinical Laboratory Improvement Amendments - CLIA - Certification, ISO 15189). The Oncotype DX analysis methodology and the strong quality standard imposed lead to a highly standardized and validated test.

\section{Analysis}

The procedure in based on the extraction of RNA from formalin-fixed and paraffin-embedded tumour tissue (FFPE) treated with Deoxyribonuclease I (DNase I). The total amount of RNA is then measured, after verifying the absence of a DNA contamination. Once RT-PCR is performed, the expression of each of the 16 selected genes is evaluated in triplicate and then normalized to the expression of the 5 reference genes (Figure 2). This normalization minimizes any sources of pre-analytical variability [15].

The results of this analysis are then combined, using an algorithm, into a single score known as Recurrence Score (RS) result, expressed on a continuous scale from 0 to 100 . The RS results provides for the patients the probability of $\mathrm{CT}$ benefit in addition to hormone therapy over the next 9 years, with a $95 \%$ confidence interval (CI). The quantitative nature of the PCR allows a continuous score to be obtained, which differs from the binary result (only low or high) provided by other tests (Figure 3).

\begin{tabular}{|c|c|c|}
\hline Proliferation & Invasion & HER2 \\
Ki-67 & Stromelysin 3 & GRB7 \\
STK15 & Cathepsin L2 & HER2 \\
Survivin & & \\
Cyclin B1 & & \\
MYBL2 & & Reference \\
\hline Estrogens & Other & Beta-actin \\
ER & GSTM1 & GAPDH \\
PR & CD68 & RPLPO \\
BCl-2 & BAG1 & GUS \\
SCUBE2 & & TFRC \\
\hline
\end{tabular}

Figure 2: Specific cancer genes and reference cancer genes analized with the Oncotype DX text. Abbreviations: STK15: Serine/Treonine kinasi 15; MYBL2: Myb-related protein B; GRB7: Growth factor receptor-bound protein 7; HER2: human epidermal growth factor receptor 2; ER: Estrogen receptor; PR: Progesterone receptor; Bcl-2: B-cell lymphoma 2; SCUBE2: Peptide signal, CUB damain, epidermal growth factor receptor-like 2; GSTM1: Glutathione S-transferase mu 1; CD68: Cluster differentiation 68; BAG1: Bcl-2 associated athanogene-1; GAPDH: Glyceraldehyde-3-Phosphate Dehydrogenase; RPLPO: Large Ribosomal Protein; GUS: glucuronidase; TFRC: Transferrine receptor. 


\section{VALIDATION STUDIES}

\section{Analytical validation}

An analytical validation process was put in place for the Oncotype DX test too, in order to ensure that the laboratory procedures implemented to calculate the RS results were accurate, precise and reproducible.

The validation of the test was performed for the single genes used in the test as well as for the results obtained with the RS results. The studies performed confirmed the reproducibility, the accuracy and the precision of the test, and showed that the RS results are expressed in a more dynamic range than other analytical methods. In addition, sensitivity, specificity, detection and quantification limits, amplification efficiency and test success rates were demonstrated, confirming that the test performance (in terms of uniformity in amplification efficiency for different genes and linearity) was maintained over a wide range [15].

\section{Clinical validation of the prognostic value}

The clinical validation studies of Oncotype DX test were mostly performed in 2 different populations node-negative patients and node-positive HR+, HER2early breast cancer patients. Table 2 summarizes the studies which evaluated the prognostic and predictive value of Oncotype DX test.

The first study [16] validating RS results and the prognostic value of the Oncotype DX test (probability of recurrence at 10 years) was performed on biopsy samples of 668 patients with ER+ node-negative breast cancer, enrolled in the NSABP- B14 study originally conducted to evaluate the efficacy of 5 years of adjuvant treatment. The results showed that:
- RS results 0-17 was observed in 338 patients (51\% low-risk patients) with a relapse rate of $6.8 \%$ at 10 years

- RS results 18-30 was observed in 149 patients ( $22 \%$ intermediate risk patients) with a relapse rate of $14.3 \%$ at 10 years

- RS results 31-100 was observed in 181 patients ( $27 \%$ high risk patients) with a relapse rate of $30.5 \%$ at 10 years.

The predicted relapse risk with the RS results was independent of other factors such as age, size and tumour grade (Figure 4).

The prognostic value of the Oncotype DX test was also validated in node-positive patients enrolled in the TransATAC trial $[20,30]$. The RS results were significantly prognostic for the 9-years disease-free survival.

A further prospective study, WSG-plan B [26], enrolled node-negative patients at high risk and Patients node-positive patients with Recurrence Score results 0-11 Patients were treated with hormone therapy alone and showed that CT could be avoided. Patients with Recurrence Score results above 12 were randomized to different CT regimens: for this reason, they do not support the prognostic value in patients treated with hormone therapy alone.

\section{Clinical validation of the predictive value}

The Oncotype DX test was the first and, so far the only, validated test able to identify chemo-sensitive patients who can obtain the highest benefit from adjuvant CT.

\section{NSABP-20 trial $[18,31]$}

Biopsy samples from the NSABP B-20 trial, which enrolled 651 patients with ER+ lymph node

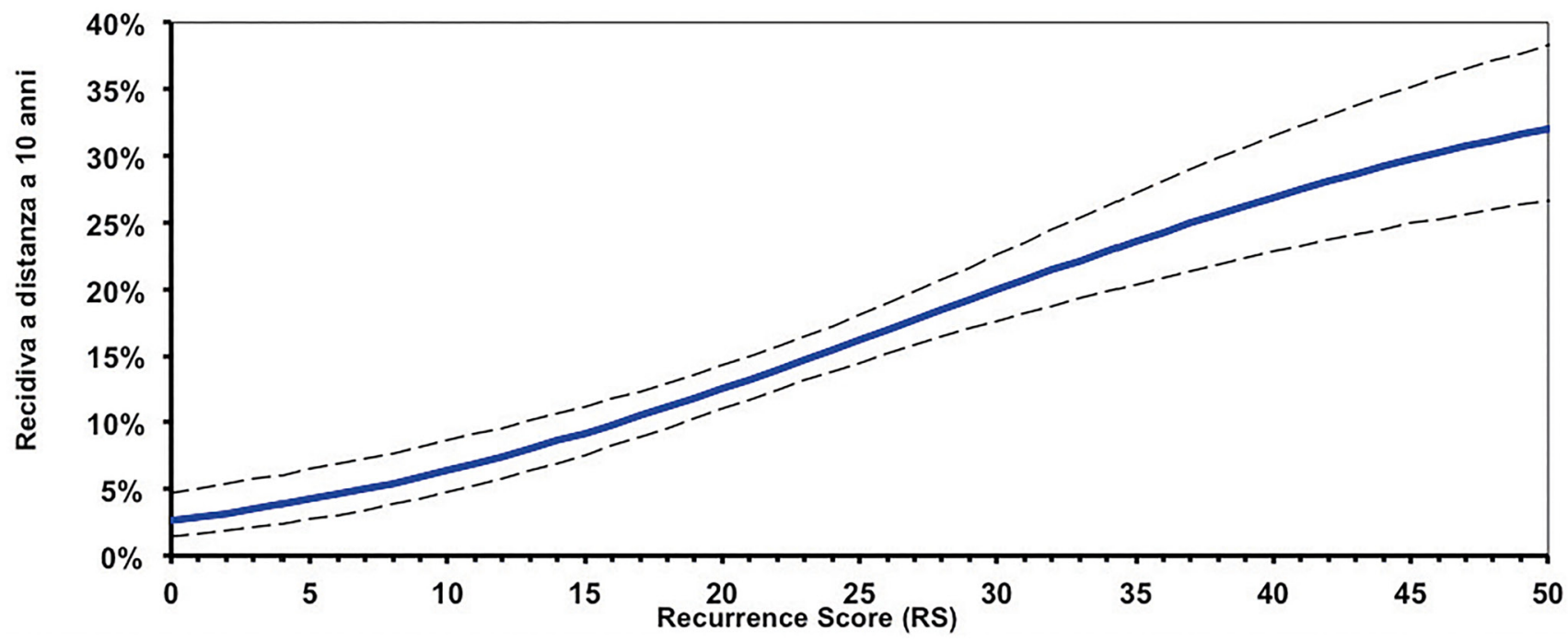

Figure 3: Continuous correlation between Recurrence Score (RS) results and risk of relapse. 
Table 2: Clinical studies and real-world evidence with the Oncotype DX test

\begin{tabular}{|c|c|c|c|c|c|c|}
\hline Reference & Study type & $\begin{array}{c}\mathrm{N} \\
\text { patients }\end{array}$ & Treatment & Nodal status & $\begin{array}{l}\text { Prognostic } \\
\text { value }\end{array}$ & $\begin{array}{l}\text { Predictive } \\
\text { value }\end{array}$ \\
\hline Paik et al. 2004 [16] & $\begin{array}{l}\text { Prospective- } \\
\text { Retrospective }\end{array}$ & 668 & adjuvant ET & pN0: $100 \%$ & Yes & - \\
\hline Gianni et al. 2005 [17] & Retrospective & 89 & neoadjuvant $\mathrm{CT}$ & $\begin{array}{l}\text { cN0: } 16 \% \\
\mathrm{cN}+: 84 \%\end{array}$ & - & Yes \\
\hline Paik et al. 2006 [18] & $\begin{array}{l}\text { Prospective- } \\
\text { Retrospective }\end{array}$ & 651 & $\begin{array}{l}\text { randomized adjuvant } \\
\text { ET or ET }+\mathrm{CT}\end{array}$ & pN0: $100 \%$ & Yes & Yes \\
\hline Chang et al. 2008 [19] & $\begin{array}{l}\text { Prospective- } \\
\text { Retrospective }\end{array}$ & 80 & neoadjuvant $\mathrm{CT}$ & $\begin{array}{l}\text { cN0: } 90 \% \\
\text { cN+: } 10 \%\end{array}$ & - & Yes \\
\hline Dowsett et al. $2010[20]$ & $\begin{array}{l}\text { Prospective- } \\
\text { Retrospective }\end{array}$ & 1.231 & adjuvant ET & $\begin{array}{l}\text { pN0: } 71 \% \\
\text { pN+: } 25 \%\end{array}$ & Yes & - \\
\hline Albain et al. 2010 [21] & $\begin{array}{l}\text { Prospective- } \\
\text { Retrospective }\end{array}$ & 367 & $\begin{array}{l}\text { randomized adjuvant } \\
\text { ET or ET }+\mathrm{CT}\end{array}$ & $\mathrm{pN}+: 100 \%$ & Yes & Yes \\
\hline Petkov et al. 2016 [22] & $\begin{array}{l}\text { Prospective } \\
\text { Registry }\end{array}$ & 25.714 & $\begin{array}{c}\text { adjuvant ET or } \\
\mathrm{ET}+\mathrm{CT}\end{array}$ & $\begin{array}{l}\text { pN0: } 82 \% \\
\text { pN+: } 18 \%\end{array}$ & Yes & - \\
\hline Roberts et al. 2017 [23] & $\begin{array}{l}\text { Prospective } \\
\text { Registry }\end{array}$ & 6.768 & $\begin{array}{c}\text { adjuvant ET or } \\
\mathrm{ET}+\mathrm{CT}\end{array}$ & $\mathrm{pN}+: 100 \%$ & Yes & - \\
\hline $\begin{array}{l}\text { Stemmer et al. } 2017 \\
{[24]}\end{array}$ & $\begin{array}{l}\text { Prospective } \\
\text { Registry }\end{array}$ & 1.801 & $\begin{array}{c}\text { adjuvant ET or } \\
\mathrm{ET}+\mathrm{CT}\end{array}$ & pN0: $100 \%$ & Yes & - \\
\hline $\begin{array}{l}\text { Stemmer et al. } 2019 \\
{[25]}\end{array}$ & $\begin{array}{l}\text { Prospective } \\
\text { Registry }\end{array}$ & 1.365 & $\begin{array}{c}\text { adjuvant ET or } \\
\mathrm{ET}+\mathrm{CT}\end{array}$ & pN1 : $100 \%$ & Yes & - \\
\hline Nitz et al. 2017 [26] & Prospective & 2.642 & adjuvant ET & $\begin{array}{l}\mathrm{pN} 0: 59 \% \\
\mathrm{pN}+: 41 \%\end{array}$ & Yes & - \\
\hline $\begin{array}{l}\text { Mamounas et al. } 2018 \\
{[27]}\end{array}$ & $\begin{array}{l}\text { Prospective- } \\
\text { Retrospective }\end{array}$ & 1.065 & adjuvant $\mathrm{ET}+\mathrm{CT}$ & $\mathrm{pN}+: 100 \%$ & Yes & - \\
\hline $\begin{array}{l}\text { Sparano et al. } 2018[28] \\
\text { Sparano et al. } 2019 \text { [29] }\end{array}$ & $\begin{array}{l}\text { Prospective } \\
\text { randomised }\end{array}$ & 10.273 & $\begin{array}{l}\text { randomized adjuvant } \\
\text { ET or ET }+ \text { CT }\end{array}$ & pN0: $100 \%$ & Yes & Yes \\
\hline
\end{tabular}

Abbreviations: CT: chemotherapy; ET: endocrinotherapy.

\section{Proportion without distant recurrence}

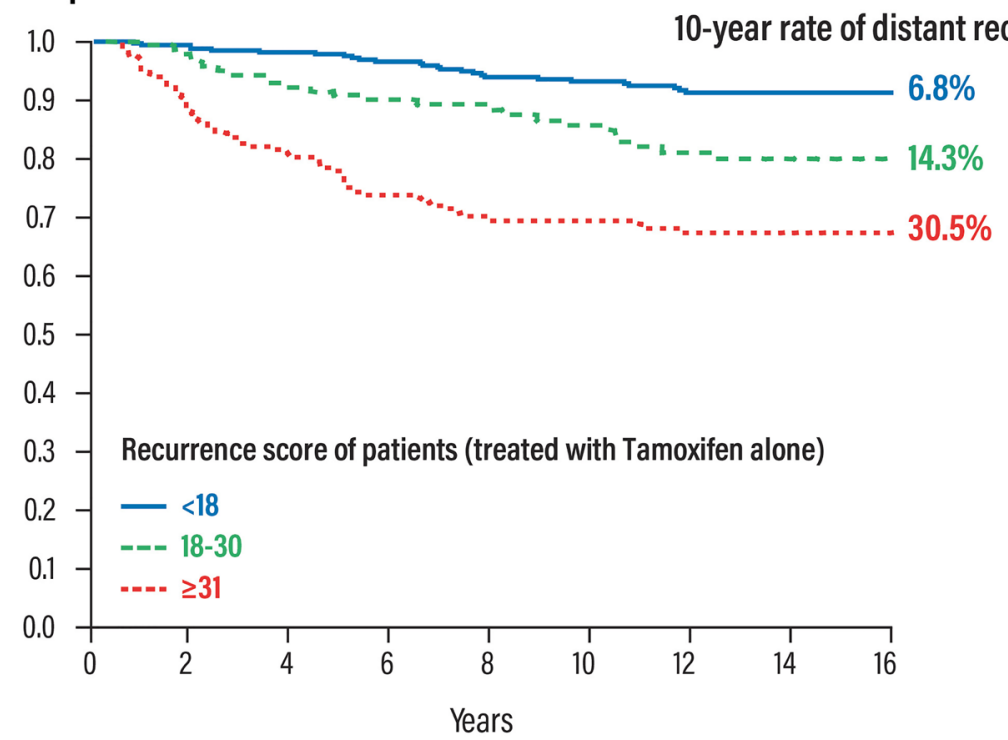

Figure 4: Prognostic validation of the Oncotype DX test in patients with early HR+ and nodes negative breast cancer. 
negative breast cancer, randomized to tamoxifen (227 patients) o tamoxifen plus CT (424 patients; CMF: cyclophosphamide/methotrexate/5-fluorouracil, or MF: methotrexate/5-fluorouracil) were used to assess the prognostic and predictive value of the Oncotype DX test. The trial was firstly analysed in order to demonstrate the predictive value of the Oncotype DX test [18]. The analysis has been revised to exclude HER2-positive patients initially included and to better define the cut-off value of the test [31].

The study showed that patients with RS results $31-$ 100 had a significant benefit from the addition of CT, with a $26 \%$ increase in the relapse-free survival ( $88 \%$ vs. $62 \%$ ); on the contrary, patients with RS results $0-17$ did not benefit at all from CT (Figure 5). The Recurrence Score result is a predictive factor for the benefit of CT (test for interaction between CT and RS groups statistically significant with $P=0.014$ ).

\section{TAILORx trial $[28,32]$}

The predictive value of the Oncotype DX test to identify patients who could omit CT was further validated by the prospective randomized clinical trial TAILORx (Trial Assessing Individualized Options for Treatment) on 10,273 enrolled patients with ER+, HER2-negative N0 early breast cancer. The objective of this study was to evaluate the non-inferiority of hormone therapy versus chemo-hormone therapy in patients with RS results 11-25.

In the TAILORx trial (Figure 6) different ranges of RS results $(0-10,11-25,26-100)$ were used in order to minimize the risk of under-treating the high-risk patients
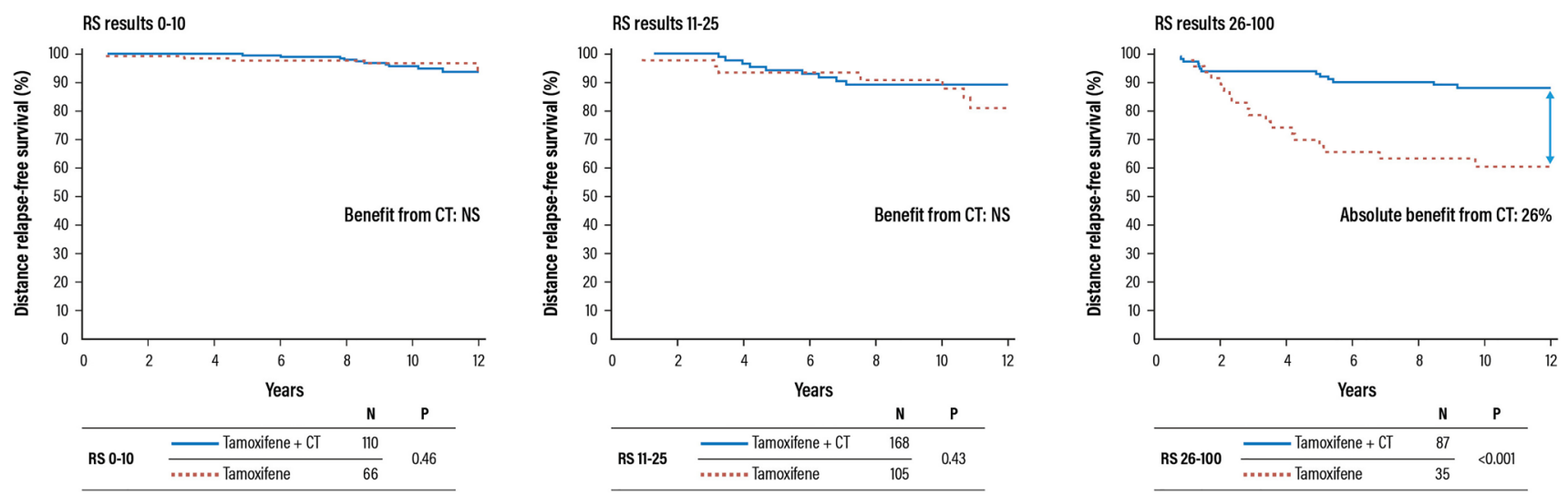

Figure 5: Validation trial of the Oncotype DX test for the identification of chemosensitive patients (HR+ and negative lymph notes). Abbreviations: CT: chemotherapy; HR: hazard ratio; NS: not significant; RS: recurrence score.

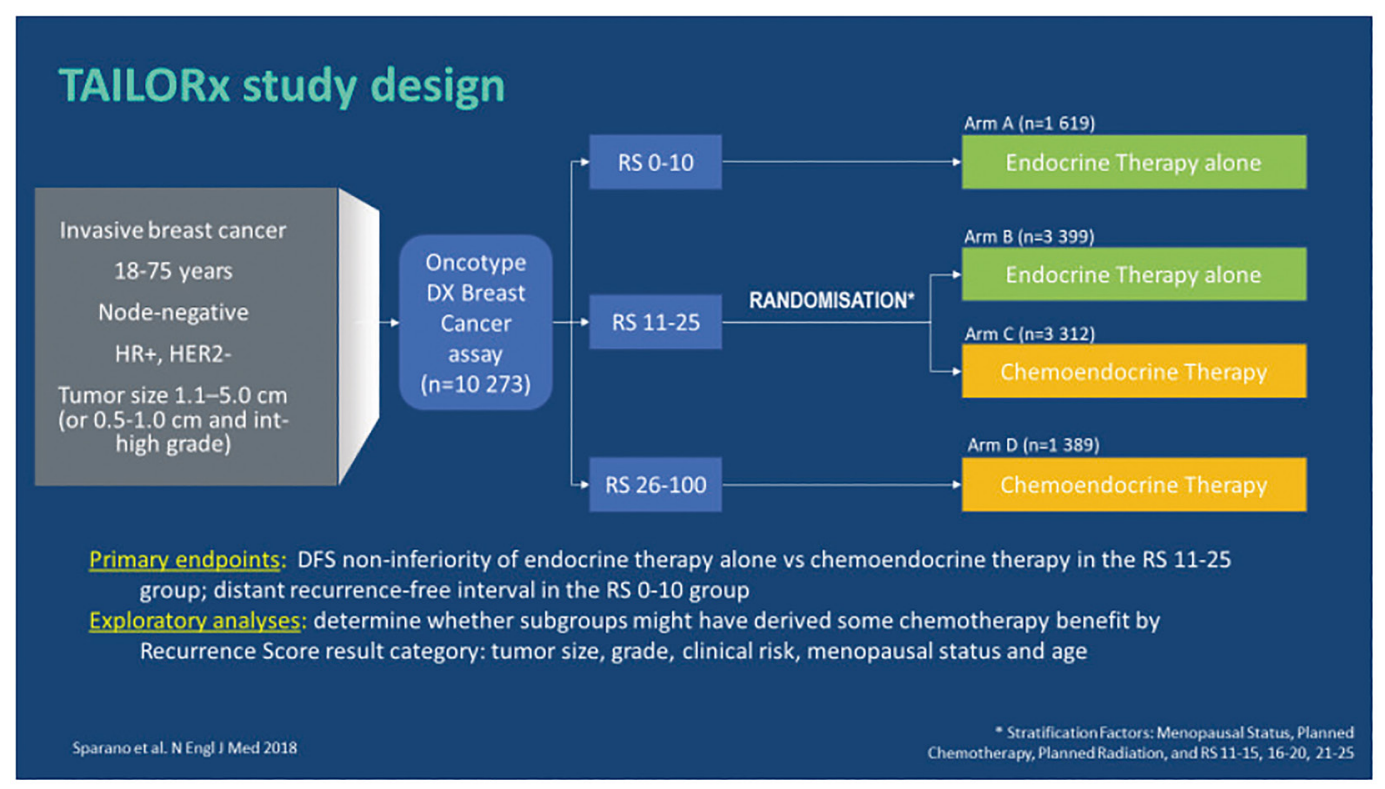

Figure 6: TAILORx: study design. Abbreviations: HER2: epidermal growth factor 2; HR: hormonal receptor; RS: recurrence score. 
as well the randomized group patients [32]. Patients were stratified in 3 treatment groups [28]:

- $\quad$ RS results $0-10 ; n=1,619 ; 17 \%$ of patients received hormone therapy alone;

- $\quad$ RS results $11-25 ; n=6,711 ; 69 \%$ of patients were randomized to hormone therapy alone ( $n$ $=3,399)$ or chemo-hormone therapy $(n=3,312)$;

- $\quad$ RS results $26-100 ; n=1,389 ; 14 \%$ of patients received chemo-hormone therapy (CT + hormone therapy).

The primary endpoint of the TAILORx trial was the distant disease-free survival (IDFS, invasive disease-free survival, defined as the absence of metastatic relapses according to primary carcinoma or death) in patients with RS results 11-25.

The results of the study demonstrated the noninferiority of the hormone therapy respect to the chemohormone therapy (HR 1.08; CI 95\% 0.94-1.24; $p=0.26$ ), highlighting that patients with RS results 11-25 do not benefit from CT and can be treated with hormone therapy alone (Figure 7) [28].

After 9 years, the 2 randomized groups of RS 11-25 patients had similar invasive disease-free survival rates: $83.3 \%$ in patients treated with hormone therapy alone and $84.3 \%$ in patients treated with chemo-hormone therapy. Similarly, the two treatment groups had similar distant relapse-free survival rates: $94.5 \%$ and $95 \%$ for hormone and chemo-hormone therapy, respectively. At 9 years, $84 \%$ of patients with RS results $0-10$ were invasive disease-free and $96.8 \%$ distant relapse-free (Figure 8) [28].

Overall, these results show that the use of the Oncotype DX test allows to identify the small number of patients (about 20\%) who can substantially benefit from CT, saving most of them (about 80\%) from toxicity and chronic side effects related to $\mathrm{CT}$.

A study was performed in patients enrolled in the TAILORx study for whom both tumour size and histological grade data were available $(97 \%$ of the total). 6615 out of the 9427 women with tumour size and histological grade data available had a low clinical risk $(70.2 \%)$ and $2812(29.8 \%)$ were classified as "high clinical risk". A significant proportion (73\%) of patients with RS results $0-25$ had a high clinical risk and would have been over-treated if the decision on CT had been based on clinical risk parameters only (Figure 9). The RS was high (a score of 26 to 100) in 589 patients (9\%) with low clinical risk. These patients would have been undertreated (Figure 9) [28].

The TAILORx trial shows that patients with RS results $0-25$ do not benefit from CT. The NSABP 20 trials shows that patients with RS results 26-100 significantly benefit from CT.

\section{Secondary analysis of the TAILORx trial [29]}

Sparano et al. performed secondary analyses of the TAILORx trial in order to establish whether the age and clinical risk, evaluated through modified Adjuvant!Online, a web-based tool that provides

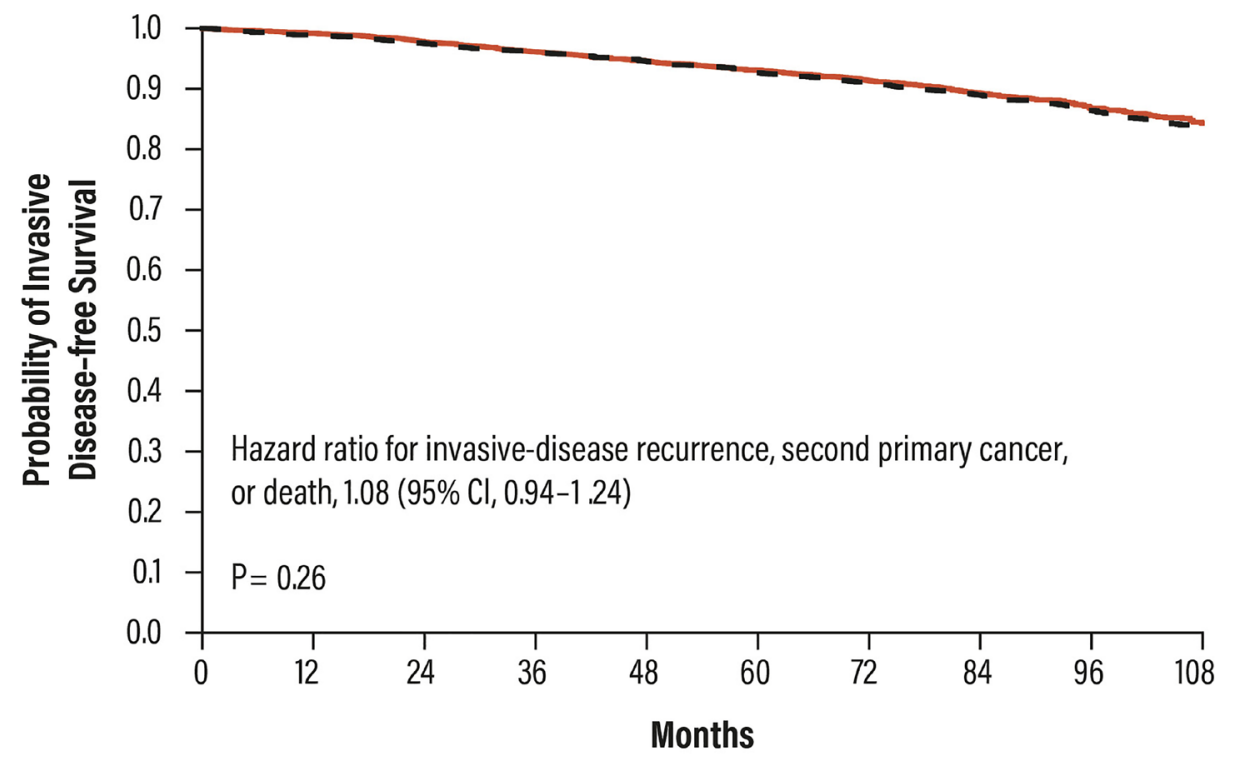

\section{No. at Risk}

— Chemoendocrine therapy 3312

- - Endocrine therapy
320

3293

3104

3194
2993

3081
2849

2953
2645

2741
2335

2431

$1859 \quad 1197$
523

537

Figure 7: Distant disease-free survival in patients with RS results 11-25 in the TAILORx trial. Abbreviations: CI: confidence interval. 
estimates of adjuvant therapy outcomes for individual patients, could add prognostic information to $\mathrm{RS}$ results and/or predictive information regarding the benefit of CT. While patients aged $>50$ years and RS results 11-25 did not benefit from $\mathrm{CT}$, younger patients (age $\leq 50$ years) started to show some benefit from $\mathrm{CT}$ with a RS result 16 . The differences observed in this unplanned exploratory analysis, although not statistically significant, could have clinical relevance. This observation was further assessed showing that in 476 women with RS results 21-25, the absolute benefit of the $\mathrm{CT}$ in the low-clinical risk subgroup $(6.4 \pm 4.9 \%)$ was similar to that of the high-clinical risk subgroup (8.7 $\pm 6.2 \%$ ). In the 886 women with RS results $16-20$, an estimated benefit of CT was observed in the high-clinical risk subgroup $(6.5 \pm 4.9 \%)$ but not in the low-clinical risk subgroup $(-0.2 \pm 2.1 \%)[29]$.

These results suggest that clinical-pathological risk factors, while by themselves are not able to predict a benefit from CT, they can help to optimize treatment decisions when used in combination with RS results, especially around cut-off values (Figure 10).

\section{SWOG 8814 trial [21]}

In order to evaluate the prognostic and predictive value of the Oncotype DX test in $\mathrm{HR}+$ and positive lymph nodes patients, biopsy samples of 367 patients randomized to tamoxifen $(n=148)$ and CAF + tamoxifen $(n=291)$ enrolled in the SWOG8814 trial were retrospectively analysed.

The results showed that:

- The RS result is highly prognostic (progressionfree survival) in the group of patients treated with tamoxifen only (Figure 11).

- The RS result is a strong predictor of the benefit from CT during the first 5 years $(p=0.029)$.

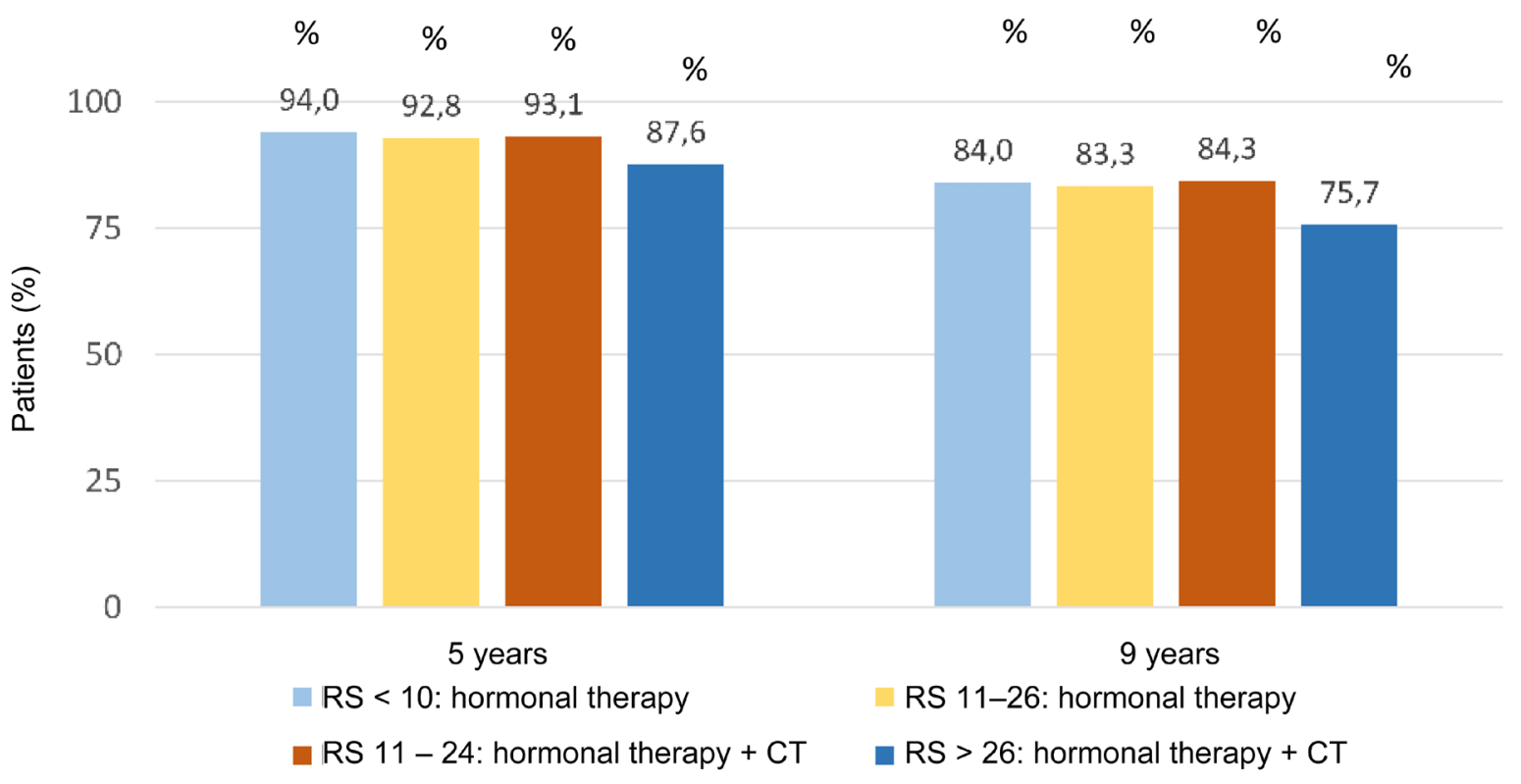

Figure 8: Invasive disease-free survival for RS results in TAILORx trail. Abbreviations: CT: chemotherapy; RS: recurrence score.

\begin{tabular}{|l|l|c|c|}
\hline & & \multicolumn{2}{|c|}{ Recurrence Score results } \\
\hline & & $0-25$ & $26-100$ \\
\hline \multirow{3}{*}{ Clinical risk } & Low & $\mathbf{9 1 \%}$ & $9 \%$ \\
& $(\mathrm{n}=6615)$ & & (under-treated) \\
\cline { 2 - 4 } & High & $73 \%$ & $\mathbf{2 7 \%}$ \\
& $(\mathrm{n}=2812)$ & (over-treated) & \\
\hline
\end{tabular}

Figure 9: Proportion of high and low clinical risk patients with RS results 0-25 vs. 26-100 in TAILORx trail. 


\begin{tabular}{|c|c|c|c|}
\hline & Patients $\leq 50$ years & & \\
\hline \multirow{4}{*}{$\begin{array}{l}\text { TAILORx trial: exploratory } \\
\text { analysis for age }\end{array}$} & & RS results $16-20$ & RS results 21-25 \\
\hline & $\begin{array}{l}\text { Any clinical risk } \\
\qquad(\mathrm{n}=1,362)\end{array}$ & $-1.5 \%$ & $-6.5 \%$ \\
\hline & & \multicolumn{2}{|c|}{ Absolute benefit from chemotherapy } \\
\hline & & RS results $16-20$ & RS results 21-25 \\
\hline \multirow{3}{*}{$\begin{array}{l}\text { TAILORx trial: exploratory } \\
\text { analysis for age and clinical } \\
\text { risk }\end{array}$} & $\begin{array}{l}\text { Low-clinical risk } \\
\qquad(\mathrm{n}=990)\end{array}$ & $\begin{array}{l}-0.2 \% \pm 2.1 \\
7 \% \text { of patients }\end{array}$ & $\begin{array}{c}6.4 \% \pm 4.9 \\
3 \% \text { of patients }\end{array}$ \\
\hline & $\begin{array}{l}\text { High-clinical risk } \\
\qquad(\mathrm{n}=372)\end{array}$ & $\begin{array}{c}6.5 \% \pm 4.9 \\
2 \% \text { of patients }\end{array}$ & $\begin{array}{c}8.7 \% \pm 6.2 \\
2 \% \text { of patients }\end{array}$ \\
\hline & & \multicolumn{2}{|c|}{ Absolute benefit from chemotherapy } \\
\hline \multicolumn{4}{|c|}{ Clinical risk defined via modified Adjuvant! Online } \\
\hline $\begin{array}{l}\text { Tumour size } \leq 3 \mathrm{~cm} \& G \\
\text { Tumour size } \leq 2 \mathrm{~cm} \& G \\
\text { Tumour size } \leq 1 \mathrm{~cm} \& \mathrm{G}\end{array}$ & $\begin{array}{l}\text { rade } 1 \\
\text { rade } 2 \\
\text { rade } 3\end{array}$ & & \\
\hline High risk: all other cases with $k$ & Wh values for grade & ur size & \\
\hline
\end{tabular}

Figure 10: Exploratory un-planned analysis of TAILORx trail. Abbreviations: RS: recurrence score.

A Disease-free survival

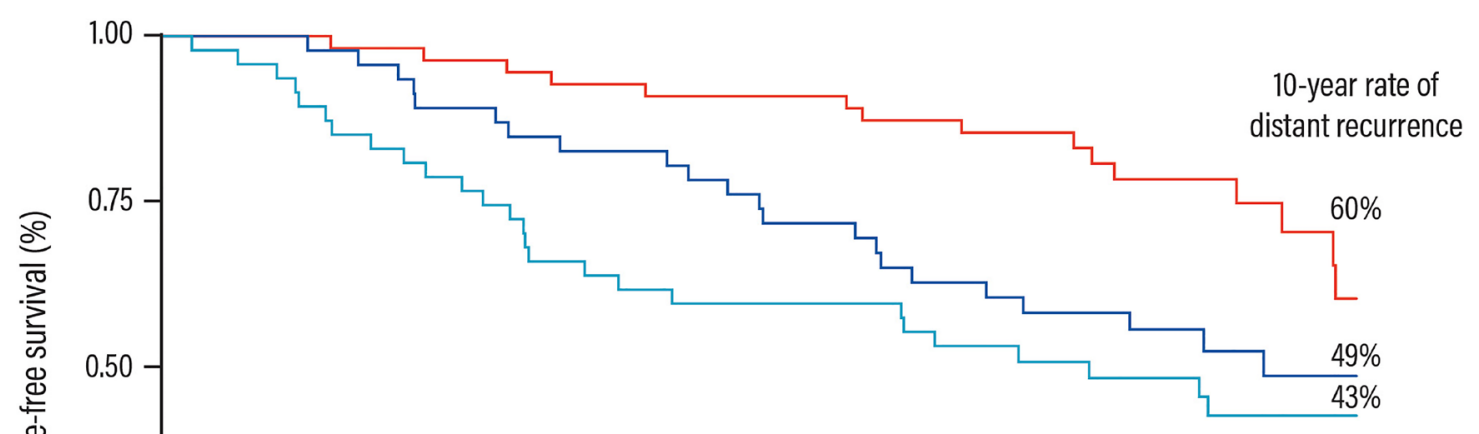

Risk category (Tamoxifen only arm)
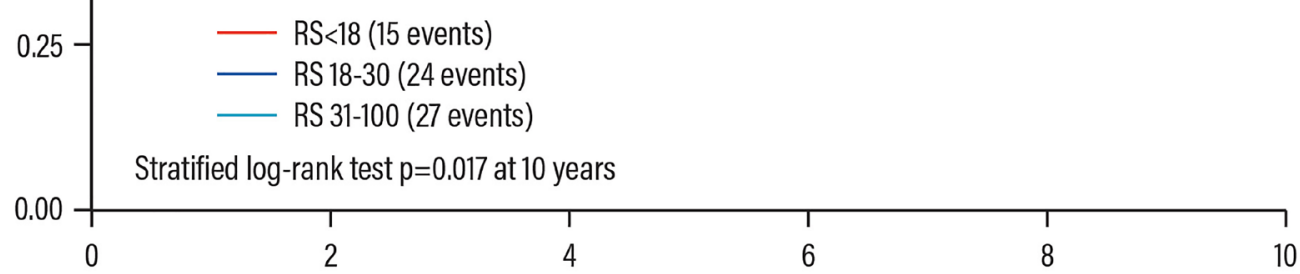

\begin{tabular}{|c|c|c|c|c|c|c|}
\hline \multicolumn{7}{|l|}{ Number at risk } \\
\hline Low & 55 & 54 & 51 & 48 & 32 & 10 \\
\hline Intermediate & 46 & 43 & 38 & 30 & 23 & 8 \\
\hline High & 47 & 39 & 29 & 28 & 20 & 8 \\
\hline
\end{tabular}

Figure 11: Prognostic validation of the Oncotype DX test in patients with HR+ early breast cancer. Abbreviations: RS: recurrence score. 
- Patients with RS results 31-100, derived a substantial 19\% benefit from CT, patients with RS 0-17 did not derive benefit from $\mathrm{CT}$ in addition to hormonal therapy (Figure 12).

\section{RXPONDER (SWOG S1007 treatment for positive node, endocrine-responsive breast cancer)}

The SWOG S1077 RXPONDER trial enrolled 5,015 patients with HR-positive, HER2-negative, stage 2-3, breast cancer involving 1-3 axillary lymph nodes and no distant metastasis. Eligible patients had RS of 0-25, indicating a low risk of recurrence. Patients were randomly assigned to receive chemotherapy plus standard adjuvant endocrine therapy $(n=2,547)$ or endocrine therapy alone $(n=2,536)$.

The primary endpoint is invasive disease-free survival (IDFS). The median follow-up of the current interim analysis is 5.1 years. Preliminary results were presented at the San Antonio Breast Cancer Symposium 2020 (ref. Oncologist. 2021 Feb; 26, Suppl 2: S11-S12). Compared with endocrine therapy alone, the addition of chemotherapy increased 5-year IDFS by $19 \%$ in the overall study population $(91.0 \%$ vs. $92.4 \% ; p=.026)$. However, when evaluated by menopausal status, the benefit was different in post vs. premenopausal women. Study findings indicate that postmenopausal women with 1-3 positive lymph nodes and an RS of 0-25 can safely forgo adjuvant chemotherapy without compromising IDFS. By comparison, premenopausal women with 1-3 positive notes and an RS of 0-25 are likely to benefit from chemotherapy added to standard adjuvant endocrine therapy.

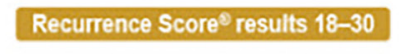

\section{Comparison trials of prognostic and predictive multigene assays}

Several trials evaluated the differences of the tests available in Italy and their possible non-interchangeability.

\section{TransATAC trial [30]}

A retrospective analysis of 774 biopsy samples from the TransATAC study, performed on post-menopausal women with ER+, HER2- breast cancer and treated for 5 years with tamoxifen or anastrazole, compared 6 tests: the Oncotype DX test, Prosigna, EndoPredict, Breast Cancer Index (BCI), Clinical Treatment Score and immunohistochemistry with 4-markers. The results showed that EndoPredict (EPclin), Prosigna and BCI can better define the prognosis. However, the results of this analysis do not seem to be conclusive, for several reasons:

- All these trials have no predictive value, and the statistical significance has been evaluated with the Chi-square method, useful from a prognostic point of view, but not from a clinical point of view.

- Compared to these trials, EPclin also includes in the evaluation clinical parameters that extend the distance between high and low risk. However, EPclin is particularly useful in attributing a prognostic value to the considered parameters, but not a predictive value of the effectiveness of CT.

These data show that these tests can be considered interchangeable from a prognostic point of view, but only
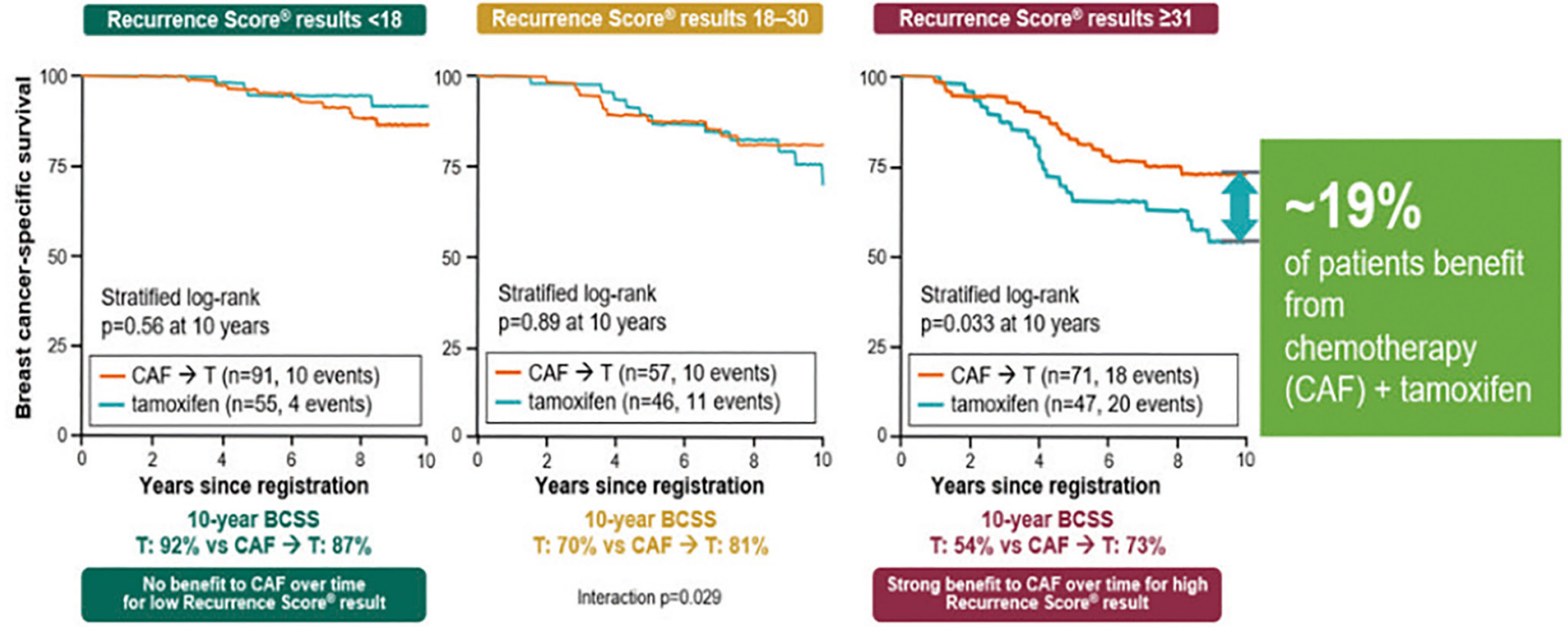

Figure 12: Validation trials of the Oncotype DX test for the identification of chemosensitive patients (HR+ and positive nodes) that could benefit from chemotherapy. Abbreviations: BCSS: breast cancer-specific survival; CAF: Cytoxan: Adriamycin and Fluorouracil. 
the Oncotype DX test is able to predict a benefit form CT (Figure 13).

\section{OPTIMA trial [33]}

The OPTIMA trial, performed in 35 UK hospitals, evaluated the outcomes of 3 out of 4 genomic tests (the Oncotype DX test, MammaPrint and Prosigna) on patients over 40 years with HR+/HER2- early breast cancer and lymph nodes involvement (1 to 9 ) or, alternatively, a T $>3 \mathrm{~cm}$ and N0. The results showed non-homogeneous risk indexes, calculated on the same sample from the same patient (Figure 14).

At individual level, the tests may give different results in terms of both risk and tumour subtype attribution (when predicted by the test).

Today, the Oncotype DX test is the only genomic test able to significantly reduce the number of patients treated with CT (17.9\% of patients; RS results 26-100) compared, for example, to MammaPrint ${ }^{\circledR}$ and Prosigna ${ }^{\circledR}$, that target a potential over-treatment $(34.5 \%$ and $38.6 \%$ of patients, respectively) $[33,34]$.

\section{Comparison of the clinical utility of the 4 tests approved in Italy}

A comparative analysis (38 studies) on the clinical utility of the 4 genomic tests was presented at the ASCO Congress 2018 [35]. The analysis focused on the use of CT in patients with ER+ lymph nodes negative early breast cancer. The results showed that the use of the Oncotype DX test is associated to a lower CT use and lower costs (Table 3).

The planned outcomes and costs were calculated on an incidence of 31 women with N0, ER + early breast cancer over 100,000 in 10 years $(n=5,574)$.
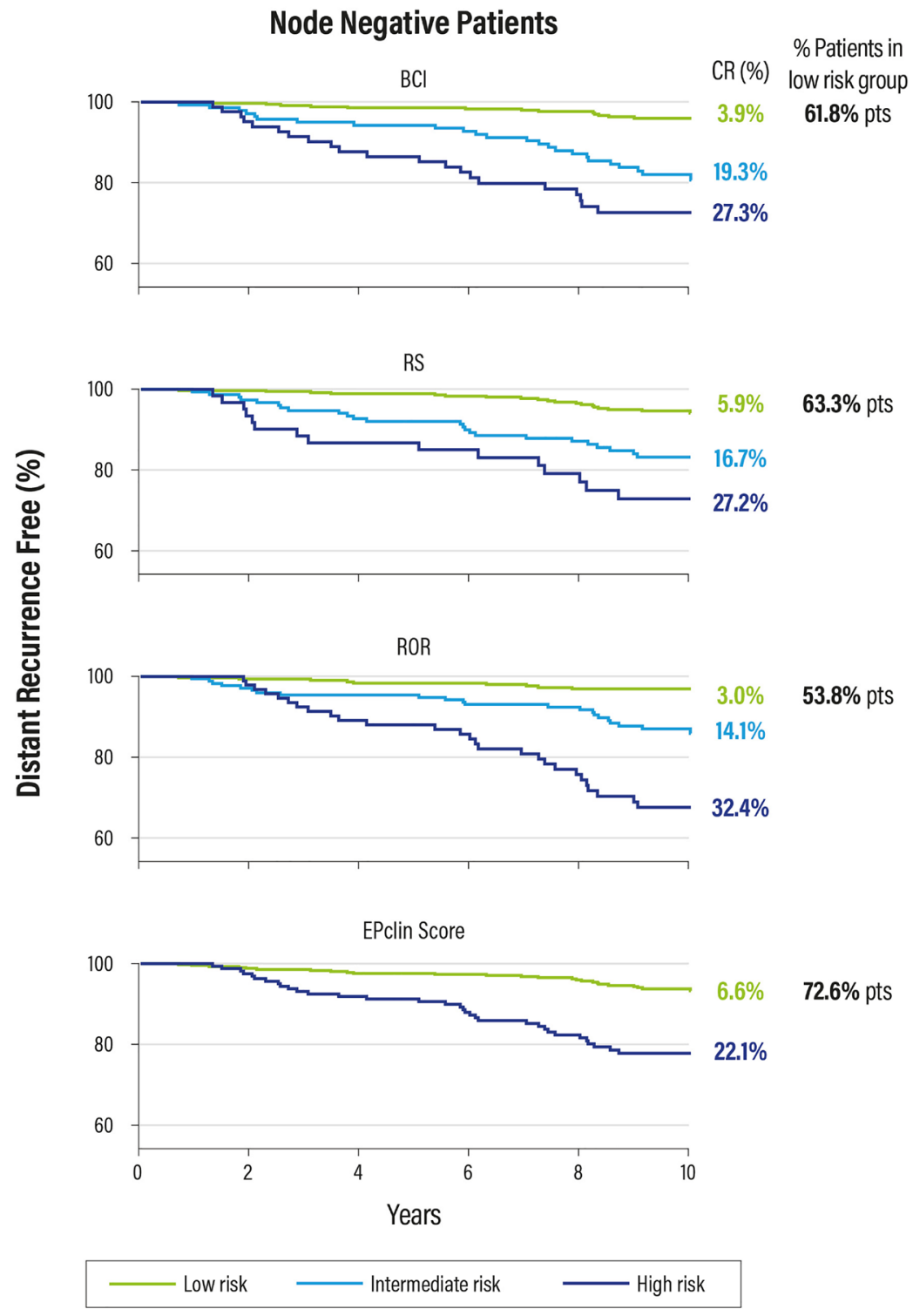

Figure 13: Kaplan Meier plot for relapse risk at 0-10 years in patients with negative nodes. 
Table 3: Comparative analysis of the effect of genomic tests on chemotherapy

\begin{tabular}{lccccc}
\hline & No test & EndoPredict & MammaPrint & Oncotype DX test & Prosigna \\
\hline CT use, \% & 51 & 56 & 64 & 31 & 49 \\
DR over 10 years, $n$ & 271 & 259 & 269 & 241 & 273 \\
ED + H over 10 years, $n$ & 2260 & 2274 & 2435 & 1630 & 2113 \\
10-tears total cost of care & $\$ 72.9 \mathrm{M}$ & $\$ 95.1 \mathrm{M}$ & $\$ 102.2 \mathrm{M}$ & $\$ 67.5 \mathrm{M}$ & $\$ 88.0 \mathrm{M}$ \\
\hline
\end{tabular}

Abbreviations: CT: Chemotherapy; DR: distant relapse; ED + H: Emergence Department + Hospitalization.

\section{THE DECISION IMPACT OF THE ONCOTYPE DX TEST ON THE CLINICAL PRACTICE}

Data from real clinical practice provide additional information to that from randomised controlled trials, allowing for a more realistic situation.

\section{The surveillance, epidemiology, and end results registry (SEER)}

Data from the SEER, which collects cancer incidence data from 1973 to date in the US population, were analyzed in an observational study involving 80,605 patients with HR+, HER2- and negative or positive lymph nodes (up to 3) early breast cancer. The results confirmed that the Oncotype DX test is able to accurately identify patients who may have a good clinical outcome with hormone therapy alone [36]. A statistically significant positive association $(p<0.001)$ was found between the RS results and breast cancer-specific mortality (BCSM) and chemotherapy after normalization by number of positive lymph nodes, age, size and tumor grade. In particular, at the 9 years follow-up, BCSM was less than $4 \%$ in N0 patients with RS results 0-25 and in N1 patients with RS results $0-17$ who had not received CT; In conclusion, a low RS result in N0 or N1 patients (up to 3 lymph nodes) was able to identify the vast majority, more than $70 \%$ of patients who have excellent long-term outcome without CT; on the contrary, high RS results (26-100) can identify the minority of patients who could significantly benefit from adjuvant CT for reducing BCSM. Real-word results from the SEER Registry confirm the high prognostic value of the Oncotype DX test and are supportive of its predictive value for the benefit from CT regardless of the nodal status.

A further analysis of the SEER registry was recently published and is particularly interesting [37] because it shows for the first time that patients undergoing the Oncotype DX test have a better overall survival than patients who were not tested. Although this analysis includes a selection bias, this is the largest and most current clinical practice-based registry evaluating the trend of the Oncotype DX test use in N0 and N1 patients.

\section{The national cancer database (NCDB)}

An interesting analysis in patients with grade 3 tumours enrolled in NCDB, a registry similar to the SEER that collects data from breast cancer patients [38]. These observations confirmed that most patients with grade 3 tumors, despite the high-clinical risk, have low RS results and excellent outcome with hormone therapy alone.

\section{The clalit registry (CHS)}

In 2006, the Israel health care system Clalit (CHS) approved the refunding of the Oncotype DX test for

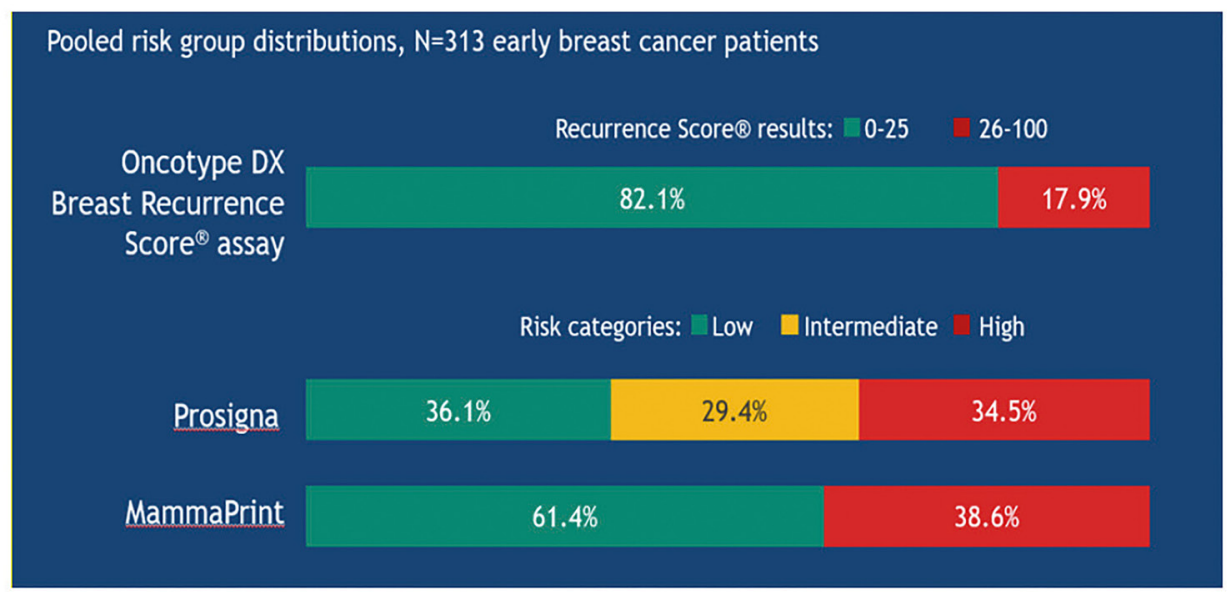

Figure 14: Risk stratification in the OPTIMA trial using different diagnostic tests in the same patients with early breast cancer. 


\begin{tabular}{|c|c|}
\hline Guidelines & Recommendation for Oncotype DX test \\
\hline IQWiG (Germany) 2020 & $\begin{array}{l}\text { With the results of TAILORx, only Oncotype DX has sufficient evidence to guide adjuvant } \\
\text { chemotherapy decisions in patients with early stage, node-negative, invasive breast cancer }\end{array}$ \\
\hline NICE (UK) 2018 & $\begin{array}{l}\text { Only test considered to predict chemotherapy benefit, therefore providing a cost-effective } \\
\text { option in patients with early stage, node-negative and micrometastatic breast cancer }\end{array}$ \\
\hline AgeNaS (Italy) 2019 & Predictive and prognostic value \\
\hline St. Gallen (EU) 2019 & $\begin{array}{l}\text { Test strongly endorsed for guiding adjuvant CT treatment decisions in both node-negative } \\
\text { and node-positive early breast cancer. TAILORx cutoffs to guide decisions in node-negative } \\
\text { patients }\end{array}$ \\
\hline ESMO (EU) 2019 & $\begin{array}{l}\text { Test may be used to gain additional prognostic and/or predictive information with } 1 \mathrm{~A} \text { evidence } \\
\text { to complement pathology assessment and to predict the benefit of adjuvant chemotherapy }\end{array}$ \\
\hline AJCC (US) 2017 & $\begin{array}{l}\text { The Oncotype DX Breast Recurrence Score test is the only multigene assay recommended to } \\
\text { guide chemotherapy decisions with level IA evidence }\end{array}$ \\
\hline ASCO (US) 2019 & $\begin{array}{l}\text { The Oncotype DX test may be used to guide decisions on adjuvant systemic chemotherapy } \\
\text { based on TAILORx cutoffs in node-negative patients with ER-positive, HER2-negative breast } \\
\text { cancer }\end{array}$ \\
\hline NCCN (US) 2020 & $\begin{array}{l}\text { Only assay recognized by NCCN Guidelines to predict adjuvant chemotherapy benefit and } \\
\text { the only assay classified as the "preferred" multigene test in node-negative patients with } \\
\text { HR-positive, HER2-negative breast cancer1 }\end{array}$ \\
\hline AIOM (Italy) 2019 & Test with prospective validation with $\mathrm{RCT}$ \\
\hline
\end{tabular}

Abbreviations: CT: chemotherapy; HER2: epidermal growth factor 2; HR: hormonal receptor; RCT: randomized clinical trial.

patients with HR+, HER2-, node-negative breast cancer and extended it in 2008 to patients with node-positive (1-3 positive nodes) disease. The data of the Clalit registry were separately analyzed for patients with negative and positive lymph nodes, respectively. The results support the use of the hormone therapy in patients with ER+ HER2- breast cancer, even in patients with positive lymph nodes (up to 3) when RS results are $0-17$ [24]. The 10-year follow-up results on 1365 patients were presented in occasion of the 16th St. Gallen International Breast Cancer Conference (Vienna 20-23 March 2019) [25]. 243 patients (17.8\%) had RS results $0-10,853(62.5 \%)$ RS results $11-25$ and $269(19.7 \%)$ RS results $26-100$. The use of CT was in line with the RS results: $0 \%$ in RS $0-10$ patients; $9.4 \%$ in RS 11-25 patients and $69.9 \%$ in RS $26-100$ patients. After 10 years, RS results were prognostic, with a clear statistical significance for the period $0-5$ years $(p<0.001)$ and a trend for the period $>5-10$ years $(p=0.134)$. In RS $0-25$ patients treated with hormone therapy only, the 10-year results are very favourable and are in line with those of similar studies (TAILORx, WGS-PlanB, SEER Registry, new analysis of NSABP B-20) for which the same cutoff values were set.

\section{PONDx study}

The PONDx programme [39] involved 1,738 patients from 27 Italian centers in 6 regions (Lombardia, Lazio, Campania, Abruzzo, Marche and Emilia Romagna). The objective of the study was to evaluate the impact of the Oncotype DX test on decisions to recommend CT or not in addition to hormone therapy, and to characterize the patients who could benefit from the use of the Oncotype DX test. The results of the survey confirmed that the Oncotype DX test can substantially modify the treatment decisions, showing an overall reduction of CT use by up to $49 \%$. Twelve percent of patients, previously recommended hormone therapy alone, were ultimately given also CT in light of the Recurrence Score results.

Reviewing the results of this PONDx study taking into account the refined cut-off values for the Recurrence Score results established with the publication of the TAILORx trial, the absolute number of patients treated with CT was estimated to be halved ( $48 \%$ to $24 \%$ ): this would lead to, overall, $75 \%$ of the patient population being treated with hormone therapy alone. Such treatment changes could lead to further potential savings for the healthcare system and to an increase of the quality of life of patients.

\section{GENOMIC TESTS IN THE MAIN GUIDELINES AND HTA BODIES}

Due to the value of the clinical evidence supporting the Oncotype DX test as the unique prognostic tool able to predict the benefit associated with CT, this test was considered by the main international guidelines (Table 4) [34]. The AIOM 2019 guidelines describe the use of Prognostic Tumor Molecular Tests (TMMP); however, at the time being, these tests are not included in the Italian 
Livelli Essenziali di Assistenza (LEA) and therefore they are not funded nationally. Therefore, they are currently used without specific institutional rules, but on the basis of the clinical needs of individual cases and the possibility for patients to directly cover the cost [1] except in Lombardy Region, where the 4 tests are reimbursed if they are used to solve therapeutic questions in complex patients. This significant limitation will be hopefully be solved soon based on the recent document: "Test prognostici multigenici (TPM) per guidare la decisione sulla chemioterapia adiuvante nel trattamento del tumore al seno in stadio precoce", where AGENAS gives a positive opinion on the clinical utility of the genomic tests.

All major tests are considered by international guidelines, whose grade of recommendation ranges from strong to moderate depending on the clinical evidence and the type of trials (prospective or retrospective). Recently, the IQWiG (German Institute for Quality and Efficiency in Healthcare) published a review on the evaluation of the benefits of genomic tests: it states that the Oncotype DX test is the only test that able to drive decisions on adjuvant $\mathrm{CT}$ in breast cancer.

The latest NCCN (National Comprehensive Cancer Network) guidelines for breast cancer also strongly recommend the Oncotype DX test as the tool able to predict the benefit from an adjuvant $\mathrm{CT}$ in patients with both node-negative and positive lymph node breast cancer; the Oncotype DX test is the only genomic test recognized as "Preferred".

According to AIOM 2019 guidelines, the highest level of evidence (IA) was conferred to the Oncotype DX test; a further confirmation comes from the inclusion of the Oncotype DX test, as the only genomic panel, in the AJCC staging manual, following the prospective level data that support its usefulness.

\section{CONCLUSIONS}

Since many patients with a HR + , HER2- early breast cancer do not benefit from an adjuvant CT, there is a need to have a molecular rationale for identifying patients who can benefit from $\mathrm{CT}$, as well those for whom $\mathrm{CT}$ would not add significant clinical benefit.

All multigene assays have a prognostic value, but only the Oncotype DX test has been shown to be able to identify which may benefit from adjuvant CT. Higher values of other genomic tests, such as Prosigna or EndoPredict, although prognostic, are not directly actionable, based on the evidence from clinical trials [13]. In addition, the MINDACT trial (Microarray In Node-Negative and 1 to 3 Positive Lymph Node Disease May Avoid Chemotherapy) demonstrated that MammaPrint has no a predictive value, because it is unable to identify patients who may benefit from CT [14].

Studies comparing different genomic tests showed that they are not interchangeable, because they provide different results: MammaPrint, Prosigna and EndoPredict can identify a higher rate of "high risk" patients than the Oncotype DX test (which defines only a minority of high risk patients), with the risk of an absolutely unjustified over-treatment without any clinical benefit.

To date, the 21-gene assay (Oncotype DX test Breast Recurrence Score) is the only test developed and validated, with a level of evidence $1 \mathrm{~A}$, to be clinically useful, i.e. able to predict the benefit from an adjuvant $\mathrm{CT}$ and therefore suitable to guide the therapeutic choice based on RS results. Clinical evidences from randomised controlled trials show that RS results 26-100 (on 0-100 scale) can predict a significant absolute benefit from the adjuvant $\mathrm{CT}$, while RS results $0-25$ indicate a minimal or totally absent benefit $[26,28]$ The scientific evidence supporting the Oncotype DX test shows that the adjuvant $\mathrm{CT}$ can be avoided in most HR+/HER2- patients. More attention should be given to women aged $\leq 50$ years, for whom chemotherapy benefit may be clinically relevant starting with a RS result of 16 .

\section{Author contributions}

All authors contributed to drafting or revising the article, gave final approval of the version to be published, and agree to be accountable for all aspects of the work.

\section{ACKNOWLEDGMENTS}

The editorial support was provided by Exacta Sciences and Editree.

\section{CONFLICTS OF INTEREST}

Cognetti received honoraria from Glaxo Smith Kline S.R.L., Roche S.P.A., Pfizer S.R.L., Astrazeneca S.P.A., Eli Lilly, Genomic Health S.R.L.

\section{REFERENCES}

1. Linee guida. Neoplasie della Mammella. Associazione Italiana di Oncologia Medica. 2019. https://www.aiom.it/wpcontent/uploads/2019/10/2019_LG_AIOM_Mammella.pdf.

2. Sparano JA, Zhao F, Martino S, Ligibel JA, Perez EA, Saphner T, Wolff AC, Sledge GW Jr, Wood WC, Davidson NE. Long-Term Follow-Up of the E1199 Phase III Trial Evaluating the Role of Taxane and Schedule in Operable Breast Cancer. J Clin Oncol. 2015; 33:2353-60. https://doi. org/10.1200/JCO.2015.60.9271. [PubMed]

3. Peto R, Davies C, Godwin J, Gray R, Pan HC, Clarke M, Cutter D, Darby S, McGale P, Taylor C, Wang YC, Bergh J, Di Leo A, et al, and Early Breast Cancer Trialists' Collaborative Group (EBCTCG). Comparisons between different polychemotherapy regimens for early breast cancer: meta-analyses of long-term outcome among 
100,000 women in 123 randomised trials. Lancet. 2012; 379:432-44. https://doi.org/10.1016/S0140-6736(11)616255. [PubMed]

4. Güler EN. Gene Expression Profiling in Breast Cancer and Its Effect on Therapy Selection in Early-Stage Breast Cancer. Eur J Breast Health. 2017; 13:168-74. https://doi. org/10.5152/ejbh.2017.3636. [PubMed]

5. Kim SR, Paik S. Genomics of adjuvant therapy for breast cancer. Cancer J. 2011; 17:500-04. https://doi.org/10.1097/ PPO.0b013e31823e5370. [PubMed]

6. Polley MY, Leung SC, McShane LM, Gao D, Hugh JC, Mastropasqua MG, Viale G, Zabaglo LA, Penault-Llorca F, Bartlett JM, Gown AM, Symmans WF, Piper T, et al, and International Ki67 in Breast Cancer Working Group of the Breast International Group and North American Breast Cancer Group. An international Ki67 reproducibility study. J Natl Cancer Inst. 2013; 105:1897-906. https://doi. org/10.1093/jnci/djt306. [PubMed]

7. Conner-Spady BL, Cumming C, Nabholtz JM, Jacobs $\mathrm{P}$, Stewart D. A longitudinal prospective study of healthrelated quality of life in breast cancer patients following high-dose chemotherapy with autologous blood stem cell transplantation. Bone Marrow Transplant. 2005; 36:251-59. https://doi.org/10.1038/sj.bmt.1705032. [PubMed]

8. Drolet M, Maunsell E, Mondor M, Brisson C, Brisson J, Mâsse B, Deschênes L. Work absence after breast cancer diagnosis: a population-based study. CMAJ. 2005; 173:76571. https://doi.org/10.1503/cmaj.050178. [PubMed]

9. Partridge AH, Burstein HJ, Winer EP. Side effects of chemotherapy and combined chemohormonal therapy in women with early-stage breast cancer. J Natl Cancer Inst Monogr. 2001; 2001:135-42. https://doi.org/10.1093/ oxfordjournals.jncimonographs.a003451. [PubMed]

10. Tao JJ, Visvanathan K, Wolff AC. Long term side effects of adjuvant chemotherapy in patients with early breast cancer. Breast. 2015 (Suppl 2); 24:S149-53. https://doi. org/10.1016/j.breast.2015.07.035. [PubMed]

11. National Institute For Health and Care Excellence. Diagnostics consultation document: Tumour profiling tests to guide adjuvant chemotherapy decisions in early breast cancer. 2018. https://www.nice.org.uk/guidance/giddg10015/documents/diagnostics-consultation-document.

12. Ballman KV. Biomarker: Predictive or Prognostic? J Clin Oncol. 2015; 33:3968-71.

13. Chang MC, Souter LH, Kamel-Reid S, Rutherford M, Bedard P, Trudeau M, Hart J, Eisen A, and Molecular Oncology Advisory Committee. Clinical utility of multigene profiling assays in early-stage breast cancer. Curr Oncol. 2017; 24:e403-22. https://doi.org/10.3747/co.24.3595. [PubMed]

14. Blok EJ, Bastiaannet E, van den Hout WB, Liefers GJ, Smit VT, Kroep JR, van de Velde CJH. Systematic review of the clinical and economic value of gene expression profiles for invasive early breast cancer available in Europe. Cancer Treat Rev. 2018; 62:74-90. https://doi.org/10.1016/j. ctrv.2017.10.012. [ [PubMed]
15. Baehner FL. The analytical validation of the Oncotype DX Recurrence Score assay. Ecancermedicalscience. 2016; 10:675. https://doi.org/10.3332/ecancer.2016.675. [PubMed]

16. Paik S, Shak S, Tang G, Kim C, Baker J, Cronin M, Baehner FL, Walker MG, Watson D, Park T, Hiller W, Fisher ER, Wickerham DL, et al. A multigene assay to predict recurrence of tamoxifen-treated, node-negative breast cancer. N Engl J Med. 2004; 351:2817-26. https:// doi.org/10.1056/nejmoa041588. [PubMed]

17. Gianni L, Zambetti M, Clark K, Baker J, Cronin M, Wu J, Mariani G, Rodriguez J, Carcangiu M, Watson D, Valagussa P, Rouzier R, Symmans WF, et al. Gene expression profiles in paraffin-embedded core biopsy tissue predict response to chemotherapy in women with locally advanced breast cancer. J Clin Oncol. 2005; 23:7265-77. https://doi. org/10.1200/JCO.2005.02.0818. [PubMed]

18. Paik S, Tang G, Shak S, Kim C, Baker J, Kim W, Cronin M, Baehner FL, Watson D, Bryant J, Costantino JP, Geyer CE Jr, Wickerham DL, Wolmark N. Gene expression and benefit of chemotherapy in women with node-negative, estrogen receptor-positive breast cancer. J Clin Oncol. 2006; 24:3726-34. https://doi.org/10.1200/JCO.2005.04.7985. [PubMed]

19. Chang JC, Makris A, Gutierrez MC, Hilsenbeck SG, Hackett JR, Jeong J, Liu ML, Baker J, Clark-Langone K, Baehner FL, Sexton K, Mohsin S, Gray T, et al. Gene expression patterns in formalin-fixed, paraffin-embedded core biopsies predict docetaxel chemosensitivity in breast cancer patients. Breast Cancer Res Treat. 2008; 108:233-40. https://doi.org/10.1007/s10549-007-9590-z. [PubMed]

20. Dowsett M, Cuzick J, Wale C, Forbes J, Mallon EA, Salter J, Quinn E, Dunbier A, Baum M, Buzdar A, Howell A, Bugarini R, Baehner FL, Shak S. Prediction of risk of distant recurrence using the 21-gene recurrence score in node-negative and node-positive postmenopausal patients with breast cancer treated with anastrozole or tamoxifen: a TransATAC study. J Clin Oncol. 2010; 28:1829-34. https:// doi.org/10.1200/JCO.2009.24.4798. [PubMed]

21. Albain KS, Barlow WE, Shak S, Hortobagyi GN, Livingston RB, Yeh IT, Ravdin P, Bugarini R, Baehner FL, Davidson NE, Sledge GW, Winer EP, Hudis C, et al, and Breast Cancer Intergroup of North America. Prognostic and predictive value of the 21-gene recurrence score assay in postmenopausal women with node-positive, oestrogen-receptor-positive breast cancer on chemotherapy: a retrospective analysis of a randomised trial. Lancet Oncol. 2010; 11:55-65. https://doi. org/10.1016/S1470-2045(09)70314-6. [PubMed]

22. Petkov VI, Miller DP, Howlader N, Gliner N, Howe W, Schussler N, Cronin K, Baehner FL, Cress R, Deapen D, Glaser SL, Hernandez BY, Lynch CF, et al. Erratum: Author Correction: Breast-cancer-specific mortality in patients treated based on the 21-gene assay: a SEER populationbased study. NPJ Breast Cancer. 2018; 4:17. https://doi. org/10.1038/s41523-018-0069-3. [PubMed] 
23. Roberts MC, Miller DP, Shak S, Petkov VI. Breast cancerspecific survival in patients with lymph node-positive hormone receptor-positive invasive breast cancer and Oncotype DX Recurrence Score results in the SEER database. Breast Cancer Res Treat. 2017; 163:303-10. https://doi.org/10.1007/s10549-017-4162-3. [PubMed]

24. Stemmer SM, Steiner M, Rizel S, Soussan-Gutman L, Ben-Baruch N, Bareket-Samish A, Geffen DB, Nisenbaum B, Isaacs K, Fried G, Rosengarten O, Uziely B, Svedman $\mathrm{C}$, et al. Clinical outcomes in patients with node-negative breast cancer treated based on the recurrence score results: evidence from a large prospectively designed registry. NPJ Breast Cancer. 2017; 3:33. https://doi.org/10.1038/s41523017-0034-6. [PubMed]

25. Stemmer SM, Steiner M, Rizel S, Ben-Baruch N, Uziely B, Jakubowski DM, Baron J, Shak S, Soussan-Gutman L, Bareket-Samish A, Fried G, Rosengarten O, Itay A, et al. Ten-year clinical outcomes in N0 ER+ breast cancer patients with Recurrence Score-guided therapy. NPJ Breast Cancer. 2019; 5:41. https://doi.org/10.1038/s41523-0190137-3. [PubMed]

26. Nitz U, Gluz O, Christgen M, Kates RE, Clemens M, Malter W, Nuding B, Aktas B, Kuemmel S, Reimer T, Stefek A, Lorenz-Salehi F, Krabisch P, et al. Reducing chemotherapy use in clinically high-risk, genomically low-risk pN0 and pN1 early breast cancer patients: five-year data from the prospective, randomised phase 3 West German Study Group (WSG) PlanB trial. Breast Cancer Res Treat. 2017; 165:57383. https://doi.org/10.1007/s10549-017-4358-6. [PubMed]

27. Mamounas EP, Tang G, Paik S, Baehner FL, Liu Q, Jeong JH, Kim SR, Butler SM, Jamshidian F, Cherbavaz DB, Sing AP, Shak S, Julian TB, et al. 21-Gene Recurrence Score for prognosis and prediction of taxane benefit after adjuvant chemotherapy plus endocrine therapy: results from NSABP B-28/NRG Oncology. Breast Cancer Res Treat. 2018; 168:69-77. https://doi.org/10.1007/s10549-017-4550-8. [PubMed]

28. Sparano JA, Gray RJ, Makower DF, Pritchard KI, Albain KS, Hayes DF, Geyer CE Jr, Dees EC, Goetz MP, Olson JA Jr, Lively T, Badve SS, Saphner TJ, et al. Adjuvant Chemotherapy Guided by a 21-Gene Expression Assay in Breast Cancer. N Engl J Med. 2018; 379:111-21. https:// doi.org/10.1056/NEJMoa1804710. [PubMed]

29. Sparano JA, Gray RJ, Makower DF, Albain KS, Saphner TJ, Badve SS, Wagner LI, Kaklamani VG, Keane MM, Gomez HL, Reddy PS, Goggins TF, Mayer IA, et al. Clinical Outcomes in Early Breast Cancer With a High 21Gene Recurrence Score of 26 to 100 Assigned to Adjuvant Chemotherapy Plus Endocrine Therapy: A Secondary Analysis of the TAILORx Randomized Clinical Trial. JAMA Oncol. 2020; 6:367-74. https://doi.org/10.1001/ jamaoncol.2019.4794. [PubMed]

30. Sestak I, Buus R, Cuzick J, Dubsky P, Kronenwett R, Denkert C, Ferree S, Sgroi D, Schnabel C, Baehner FL, Mallon E, Dowsett M. Comparison of the Performance of 6 Prognostic Signatures for Estrogen Receptor-Positive Breast Cancer: A Secondary Analysis of a Randomized Clinical Trial. JAMA Oncol. 2018; 4:545-53. https://doi. org/10.1001/jamaoncol.2017.5524. [ubMed]

31. Geyer CE Jr, Tang G, Mamounas EP, Rastogi P, Paik S, Shak S, Baehner FL, Crager M, Wickerham DL, Costantino JP, Wolmark N. 21-Gene assay as predictor of chemotherapy benefit in HER2-negative breast cancer. NPJ Breast Cancer. 2018; 4:37. https://doi.org/10.1038/s41523018-0090-6. [PubMed]

32. Sparano JA, Paik S. Development of the 21-gene assay and its application in clinical practice and clinical trials. J Clin Oncol. 2008; 26:721-28. https://doi.org/10.1200/ JCO.2007.15.1068. [PubMed]

33. Bartlett JM, Bayani J, Marshall A, Dunn JA, Campbell A, Cunningham C, Sobol MS, Hall PS, Poole CJ, Cameron DA, Earl HM, Rea DW, Macpherson IR, et al, and OPTIMA TMG. Comparing Breast Cancer Multiparameter Tests in the OPTIMA Prelim Trial: No Test Is More Equal Than the Others. J Natl Cancer Inst. 2016; 108:djw050. https://doi. org/10.1093/jnci/djw050. [PubMed]

34. Markopoulos C, van de Velde C, Zarca D, Ozmen V, Masetti R. Clinical evidence supporting genomic tests in early breast cancer: Do all genomic tests provide the same information? Eur J Surg Oncol. 2017; 43:909-20. https:// doi.org/10.1016/j.ejso.2016.08.012. [PubMed]

35. Hochheiser L, Hornberger JC, Turner M, Lyman GH. Comparative analysis of multigene assays (MGA) effects on chemotherapy (CT) de-escalation for women with N0, ER+ early stage breast cancer (ESBC). J Clin Oncol. 2018 (Suppl 15); 36:e12519. https://doi.org/10.1200/JCO.2018.36.15 suppl.e12519.

36. Hortobagyi GN, Shak S, Sledge GW Jr, Winer EP, Albain KS, Mamounas EP, Jakubowski DM, Petkov VI, Wolmark N. Abstract P3-11-02: Breast cancer-specific mortality (BCSM) in patients (pts) with node-negative (N0) and node-positive $(\mathrm{N}+)$ breast cancer $(\mathrm{BC})$ guided by the 21gene assay: A SEER-genomic population-based study. Cancer Res. 2019; 79. https://doi.org/10.1158/1538-7445. SABCS18-P3-11-02.

37. Zhang L, Hsieh MC, Petkov V, Yu Q, Chiu YW, Wu XC. Trend and survival benefit of Oncotype DX use among female hormone receptor-positive breast cancer patients in 17 SEER registries, 2004-2015. Breast Cancer Res Treat. 2020; 180:491-501. https://doi.org/10.1007/s10549-02005557-x. [PubMed]

38. Iorgulescu JB, Freedman RA, Lester SC, Mittendorf EA, Brock JE. 21-Gene Recurrence Score Adds Significant Value for Grade 3 Breast Cancers: Results From a National Cohort. JCO Precis Oncol. 2019; 3:1-15. https://doi.org/10.1200/ po.19.00029. [PubMed]

39. Barni S, Cognetti F, Vassali L. PONDx: a perspective multicenter Italian survey of the 21-gene assay: impact on treatment selection in lobular breast cancer patients. Tumori Journal. 2018; 104:16-17. 